\title{
ANALISIS FAKTOR YANG MEMPENGARUHI KONSUME DALAM PENGAMBILAN KEPUTUSAN PEMBELIAN PRODUK AIR MINUM MERK AQUA (Studi kasus di UD Budi Jaya Kediri)
}

\author{
M. Dian Ruhamak
}

Dosen Universitas Kadiri

\begin{abstract}
Abstrak
Tujuan dari penelitian ini adalah untuk menganalisis faktor-faktor budaya, sosial, pribadi dan psikologis yang mempengaruhi Konsumen dalam pengambilan keputusan membeli produk air minum merk aqua karena diproduksi secara masal maka peneliti mengambil 40 responden secara accidental. Alat yang digunakan untuk menguji penelitian ini adalah regresi linear berganda. Hasil uji analisis didapat bahwa variabel faktor budaya, sosial, pribadi dan psikologis secara parsial, faktor budaya dan faktor sosial mempunyai pengaruh yang tidak signifikan (bermakna) tetapi faktor pribadi dan faktor psikologis mempunyai pengaruh yang signifikan (bermakna) terhadap keputusan pembelian produk air minum merk aqua. Variabel psikologis mempunyai pengaruh dominan terhadap keputusan pembelian produk air minum merk aqua
\end{abstract}

Kata kunci : budaya, sosial, pribadi, psikologis, keputusan

\section{PENDAHULUAN}

Air merupakan kebutuhan utama dalam kehidupan sehari-hari. Saat ini air minum kemasan menjadi alternatif untuk memenuhi kebutuhan akan minuman. Ini terjadi karena selain praktis, harga air minum relatif murah dan tersedia Seiring dengan perkembangan industri air minum kemasan di Indonesia di masa kini, semakin banyak pula produsen air minum berlomba - lomba memasarkan produknya.

Produk air minum merk aqua sebagaimana diketahui adalah salah satu produk air minum yang semakin lama semakin banyak digemari masyarakat karena diambil dari sumber mata air yang bersih dan jernih dengan beberapa kali proses penyaringan sehingga sehat untuk dikonsumsi dan baik untuk mengganti cairan dalam tubuh. Demikian juga bagi kalangan masyarakat yang sebagian besar berdomisili di kota Situbondo, produk ini merupakan produk yang biasa dikonsumsi karena harganya yang terjangkau, mudah didapatkan dan sifatnya menyehatkan tubuh. Dengan semakin banyaknya air minum yang ada di pasaran berarti memberikan keleluasaan bagi konsumen untuk memilih merk yang sesuai dengan keinginannya. Oleh karena itu perlu bagi perusahaan untuk menganalisis perilaku konsumen air minum untuk mengetahui pola pembeliannya. Dengan banyaknya merk air minum yang ada di pasaran akan mendorong perusahaan bersaing mendapatkan calon konsumen melalui berbagai strategi yang tepat, misalnya mengubah kemasan, warna, aroma, promosi dan harga. Lebih jauh lagi produsen dalam mendistribusikan produknya ke pasar konsumen berusaha 
agar produknya dapat diterima sesuai dengan apa yang diinginkan konsumen.

Keanekaragaman konsumen dalam memenuhi kebutuhan sehari-hari dapat dipengaruhi oleh berbagai faktor baik yang berasal dari diri konsumen maupun luar konsumen. Beberapa faktor yang dapat mempengaruhi perilaku konsumen diantaranya adalah faktor budaya, sosial, pribadi dan psikologis.

\section{Pengertian Pemasaran}

Pengertian pemasaran mengandung pengertian yang lebih luas dari sekedar penjualan dan periklanan. Tjiptono (2002:7) memberikan definisi pemasaran adalah:

Suatu proses sosial dan manajerial dimana individu atau kelompok mendapatkan apa yang mereka butuhkan dan inginkan melalui penciptaan, pewarnaan, dan pertukaran segala sesuatu yang bernilai dengan orang atau kelompok lain.

Assauri (1999:4) mendefinisikan pemasaran: "Sebagai usaha menyediakan dan menyampaikan barang dan jasa yang tepat kepada orang-orang yang tepat pada tempat dan waktu serta harga yang tepat dengan promosi dan komunikasi yang tepat".

Joseph P. Cannon, William D. Perreault Jr., E. Jeromy McCarthy. (2008:8) definisi pemasaran: "suatu aktivitas yang bertujuan mencapai sasaran perusahaan, dilakukan dengan cara mengantisipasi kebutuhan pelanggan atau klien serta mengarahkan aliran barang dan jasa yang memenuhi kebutuhan pelanggan atau klien dari produsen."

Dari definisi di atas menunjukkan bahwa pemasaran merupakan serangkaian prinsip untuk memilih pasar sasaran (target market), mengevaluasi kebutuhan konsumen, mengembangkan barang dan jasa, pemuas keinginan, memberikan nilai kepada konsumen dan laba bagi perusahaan.

\section{Pengertian Produk}

Pada dasarnya sebagian besar keuntungan yang didapat oleh perusahaan berasal dari kepuasan konsumen dalam menikmati produknya. Konsep produksi berpendapat bahwa konsumen akan menyukai produk yang berkualitas dengan harga yang relatif murah. Untuk itu perusahaan dalam proses kegiatan produksi haruslah mengerti dan tahu dengan benar akan arti dari produk itu sendiri.

Kotler et.al (2000:212) mengemukakan bahwa produk adalah: "Segala sesuatu yang dapat ditawarkan ke pasar untuk menarik perhatian, dimiliki, digunakan atau dikonsumsi yang dapat memuaskan keinginan atau kebutuhan".

Selanjutnya produk itu dijelaskan lebih lanjut oleh Lamb, Charles et. al (2001:414): "Produk didefinisikan sebagai segala sesuatu baik yang menguntungkan maupun tidak yang diperoleh seseorang melalui pertukaran".

Dari definisi di atas dapat dijelaskan bahwa produk adalah segala sesuatu yang memiliki nilai untuk dipasarkan untuk dibeli, dipergunakan atau dikonsumsi untuk memenuhi keinginan atau kebutuhan. 


\section{Pengertian Perilaku Konsumen}

Perilaku konsumen menyangkut masalah keputusan yang diambil seseorang dalam persaingannya dan penentuan untuk mendapatkan dan mempergunakan barang dan jasa.

Konsumen mengambil banyak macam keputusan membeli setiap hari. Kebanyakan perusahaan besar meneliti keputusan membeli konsumen secara amat rinci untuk menjawab pertanyaan mengenai apa yang dibeli konsumen, dimana mereka membeli, bagaimana dan berapa banyak mereka membeli, serta mengapa mereka membeli. Pemasar dapat mempelajari apa yang dibeli konsumen untuk mencari jawaban atas pertanyaan mengenai apa yang mereka beli, dimana dan berapa banyak, tetapi mempelajari mengenai alasan tingkah laku konsumen bukan hal yang mudah, jawabannya seringkali tersembunyi jauh dalam benak konsumen.

Pengertian perilaku konsumen seperti diungkapkan oleh Mowen (2002:6) mengatakan: "Studi tentang unit pembelian (buying unit) dan proses pertukaran yang melibatkan perolehan, konsumsi dan pembuangan, barang, jasa, pengalaman serta ide-ide".

Swastha dan Handoko (2000:10) mengatakan:

Perilaku konsumen (consumer behavior) dapat didefinisikan sebagai kegiatankegiatan individu yang secara langsung terlibat dalam mendapatkan dan mempergunakan barang-barang dan jasa-jasa, termasuk didalamnya proses pengambilan keputusan pada persiapan dan menentukan kegiatan-kegiatan tertentu.

Dari pengertian di atas maka perilaku konsumen merupakan tindakan-tindakan dan hubungan sosial yang dilakukan oleh konsumen perorangan, kelompok maupun organisasi untuk menilai, memperoleh dan menggunakan barang-barang serta jasa melalui proses pertukaran atau pembelian yang diawali dengan proses pengambilan keputusan yang menentukan tindakan-tindakan tersebut.

\section{Faktor-faktor Yang Mempengaruhi Perilaku Konsumen}

Menurut Kotler (2002:183):

Faktor-faktor yang mempengaruhi perilaku konsumen adalah kebudayaan, faktor sosial, pribadi, psikologis. Sebagian faktor-faktor tersebut tidak diperhatikan oleh pemasar tetapi sebenarnya harus diperhitungkan untuk mengetahui seberapa jauh faktor-faktor perilaku konsumen tersebut mempengaruhi pembelian konsumen.

Gambar 1 : Faktor-Faktor Yang Mempengaruhi Tingkah Laku Konsumen

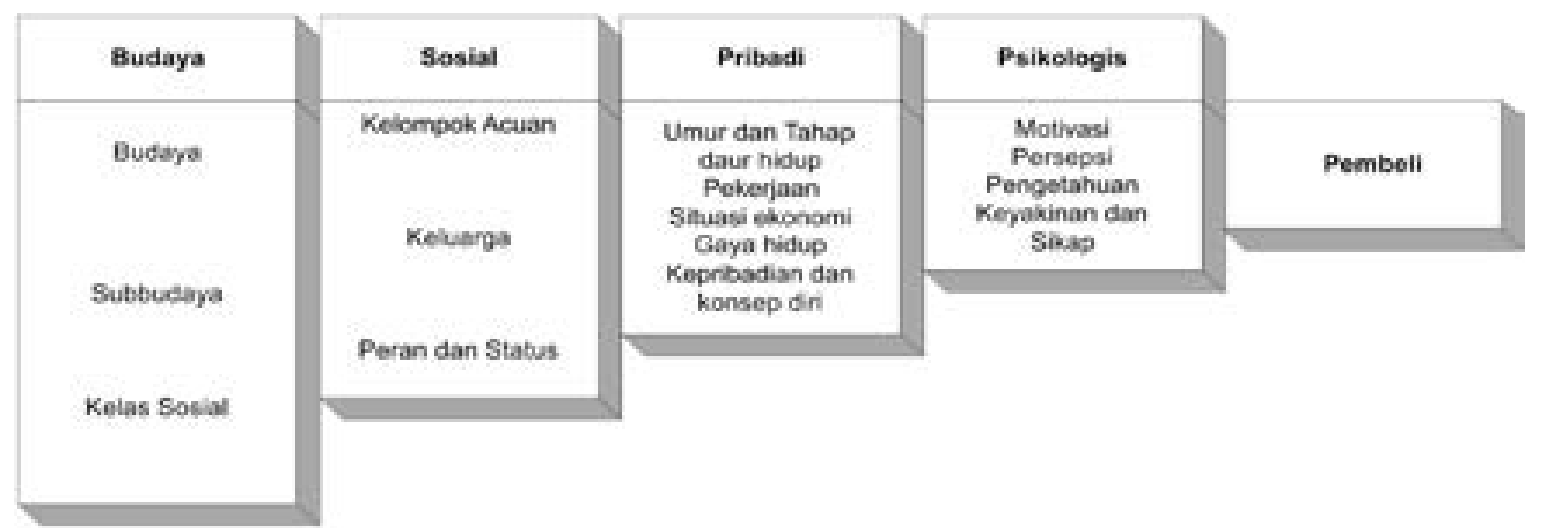

Sumber : (Kotler, 2002:183) 


\section{Proses Keputusan Membeli}

Menurut (Kotler, 2000:204) tahap-tahap yang dilewati pembeli untuk mencapai keputusan membeli melewati lima tahap, yaitu:

a. Pengenalan Masalah

b. Pencarian Informasi

c. Evaluasi alternatif

d. Keputusan Membeli

e. Tingkah laku pasca pembelian

Adapun penjelasannya adalah sebagai berikut:

a. Pengenalan masalah

Proses membeli dimulai dengan pengenalan masalah dimana pembeli mengenali adanya masalah atau kebutuhan. Pembeli merasakan perbedaan antara keadaan nyata dan keadaan yang diinginkan.

b. Pencarian informasi

Seorang konsumen yang sudah terkait mungkin mencari lebih banyak informasi tetapi mungkin juga tidak. Bila dorongan konsumen kuat dan produk yang dapat memuaskan ada dalam jangkauan, konsumen kemungkinan akan membelinya. Bila tidak, konsumen dapat menyimpan kebutuhan dalam ingatan atau melakukan pencarian informasi yang berhubungan dengan kebutuhan tersebut.

Pengaruh relatif dari sumber informasi ini bervariasi menurut produk dan pembeli. Pada umumnya, konsumen menerima sebagian besar informasi mengenai suatu produk dari sumber komersial, yang dikendalikan oleh pemasar. Akan tetapi, sumber paling efektif cenderung sumber pribadi. Sumber pribadi tampaknya bahkan lebih penting dalam mempengaruhi pembelian jasa. Sumber komersial biasanya memberitahu pembeli, tetapi sumber pribadi membenarkan atau mengevaluasi produk bagi pembeli. Misalnya, dokter pada umumnya belajar mengenai obat baru cari sumber komersial, tetapi bertanya kepada dokter lain untuk informasi yang evaluatif.

c. Evaluasi alternatif

Tahap dari proses keputusan membeli, yaitu ketika konsumen menggunakan informasi untuk mengevaluasi merk alternatif dalam perangkat pilihan. Konsep dasar tertentu membantu menjelaskan proses evaluasi konsumen. Pertama, kita menganggap bahwa setiap konsumen melihat produk sebagai kumpulan atribut produk. Kedua, konsumen akan memberikan tingkat arti penting berbeda terhadap atribut berbeda menurut kebutuhan dan keinginan unik masing-masing. Ketiga, konsumen mungkin akan mengembangkan satu himpunan keyakinan merk mengenai dimana posisi setiap merk pada setiap atribut. Keempat, harapan kepuasan produk total konsumen akan bervariasi pada tingkat atribut yang berbeda. Kelima, konsumen sampai pada sikap terhadap merk berbeda lewat beberapa prosedur evaluasi. Ada konsumen yang menggunakan lebih dari satu prosedur evaluasi, tergantung pada konsumen dan keputusan pembelian.

Bagaimana konsumen mengevaluasi alternatif barang yang akan dibeli tergantung pada masing-masing individu dan situasi membeli spesifik. Dalam beberapa keadaan, 
konsumen menggunakan perhitungan dengan cermat dan pemikiran logis. Pada waktu lain, konsumen yang sama hanya sedikit mengevaluasi atau tidak sama sekali, mereka membeli berdasarkan dorongan sesaat atau tergantung pada intuisi. Kadang-kadang konsumen mengambil keputusan membeli sendiri, kadang-kadang mereka bertanya pada teman, petunjuk bagi konsumen, atau wiraniaga untuk memberi saran pembelian.

Pemasar harus mempelajari pembeli untuk mengetahui bagaimana sebenarnya mereka mengevaluasi alternatif merk. Bila mereka mengetahui proses evaluasi apa yang sedang terjadi, pemasar dapat membuat langkah-langkah untuk mempengaruhi keputusan membeli.

d. Keputusan membeli

Dalam tahap evaluasi, konsumen membuat peringkat merk dan membentuk niat untuk membeli. Pada umumnya, keputusan membeli konsumen adalah membeli merk yang paling disukai, tetapi dua faktor dapat muncul antara niat untuk membeli dan keputusan untuk membeli. Faktor pertama adalah sikap orang lain, yaitu pendapat dari orang lain mengenai harga, merk yang akan dipilih konsumen. Faktor kedua adalah faktor situasi yang tidak diharapkan, harga yang diharapkan dan manfaat produk yang diharapkan. Akan tetapi peristiwa-peristiwa yang tak diharapkan bisa menambah niat pembelian.

e. Tingkah laku pasca pembelian

Tahap dari proses keputusan pembeli, yaitu konsumen mengambil tindakan lebih lanjut setelah membeli berdasarkan pada rasa puas atau tidak puas. Yang menentukan pembeli merasa puas atau tidak puas dengan suatu pembelian terletak pada hubungan antara harapan konsumen dengan prestasi yang diterima dari produk. Bila produk tidak memenuhi harapan, konsumen merasa tidak puas, bila memenuhi harapan konsumen merasa puas, bila melebihi harapan konsumen akan merasa puas.

Konsumen mendasarkan harapan mereka pada informasi yang mereka terima dari penjual, teman dan sumber-sumber yang lain. Bila penjual melebih-lebihkan prestasi produknya, harapan konsumen tidak akan terpenuhi dan hasilnya ketidakpuasan. Semakin besar antara kesenjangan antara harapan dan prestasi, semakin besar ketidakpuasan kosumen. Hal ini menunjukkan bahwa pembeli harus membuat pernyataan yang jujur mengenai prestasi produknya sehingga pembeli akan puas.

Proses keputusan pembelian menurut Setiadi (2003) terdiri dari lima tahap yaitu pengenalan kebutuhan, pencarian informasi, evaluasi alternatif, keputusan pembelian, paska pembelian

\section{Model hipotesis}

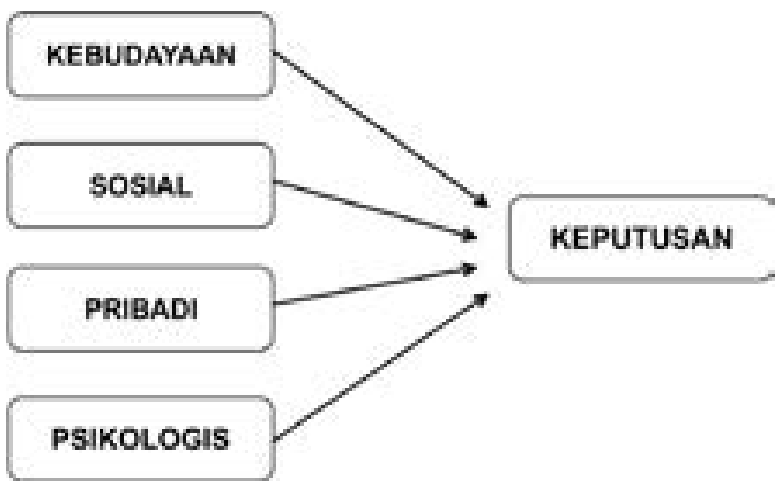




\section{Hipotesis}

Hipotesis ini merupakan jawaban sementara terhadap masalah penelitian yang kebenarannya masih harus diuji secara empiris.

Dari perumusan masalah, tujuan penelitian, landasan teori dan telah dituangkan dalam kerangka pikir, maka dapat ditarik hipotesis sebagai berikut:

1. faktor kebudayaan, sosial, pribadi dan psikologis secara parsial/terpisah berpengaruh terhadap keputusan membeli produk air minum merk aqua.

2. faktor kebudayaan, sosial, pribadi dan psikologis secara simultan/bersama-sama berpengaruh terhadap keputusan pembelian produk air minum merk aqua.

3. pengaruh psikologis berpengaruh dominan terhadap keputusan pembelian produk air minum merk aqua.

\section{METODE PENELITIAN}

\section{Rancangan Penelitian}

Penelitian ini dilakukan dengan metode survey (wawancara, quesioner dan dokumentasi) dan studi pustaka. Survey dilakukan untuk mencari data-data yang relevan dengan permasalahan yang sedang diteliti. Penelitian ini dilakukan pada Pelanggan di Kecamatan Kota Kediri yang mengkonsumsi air minum merk aqua dengan pembelian pada UD. Budi Jaya dengan tujuan untuk menentukan faktor-faktor apa yang mempengaruhi mereka dalam pengambilan keputusan membeli air minum merk Aqua.

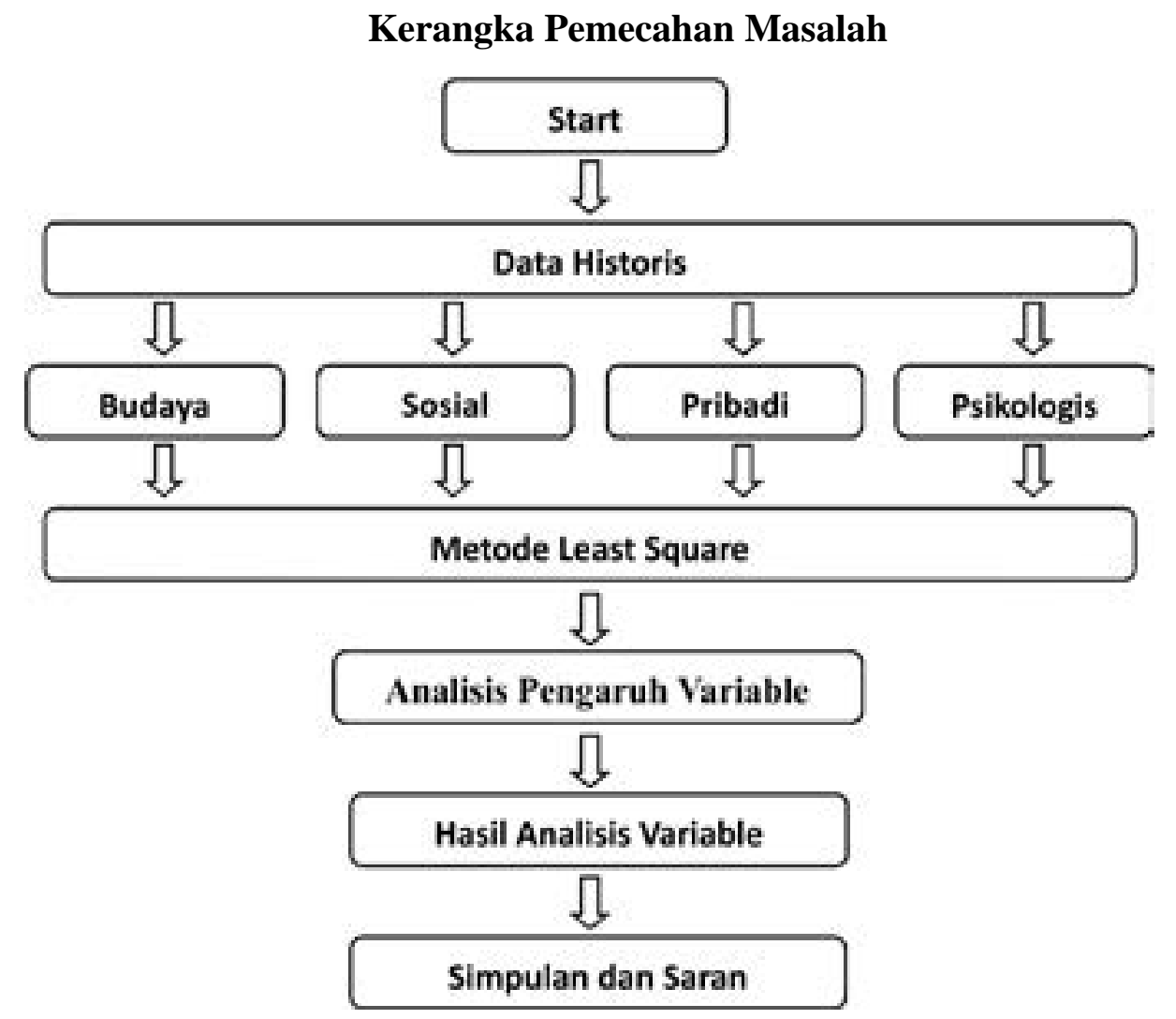

Jurnal Ekonomi Universitas Kadiri - 43 


\section{Populasi dan Sampel}

Populasi dalam penelitian ini adalah semua konsumen air mimun merk aqua masyarakat Kediri yang mempunyai kebiasaan mengkonsumsi produk air minum merk aqua, karena besar populasi tidak dapat diketahui secara pasti berapa jumlahnya, oleh karena itu sulit mencari berapa jumlah populasi yang tepat.

Namun berdasarkan pendapat ahli seperti yang dikemukakan oleh Gay (dalam Hasan, 2002:68): "ukuran sampel minimum yang dapat diterima bisa dilihat berdasarkan pada desain atau metode penelitian yang digunakan. Jika desain penelitiannya deskriptif-korelasional, maka sampel minimum adalah 30". Dan Menurut Supranto (1997:239) menyatakan bahwa: "Sampel penelitian meliputi sejumlah elemen (responden) yang lebih besar dari persyaratan minimal sebanyak 30 elemen atau responden".

Dalam penelitian ini jumlah sampel yang ditentukan oleh peneliti adalah sebesar 40 orang dengan pertimbangan terbatasnya waktu, dana dan tenaga.

Teknik pengambilan sampel yang digunakan dalam penelitian ini adalah teknik accidental sampling. Teknik accidental sampling adalah teknik penarikan sampel secara kebetulan bagi siapa saja yang kebetulan ditemui peneliti di lokasi penelitian yaitu para pelanggan air minum merk aqua pada UD. Budi Jaya per kepala keluarga untuk mewakili sebuah keluarga pengkonsumsi dimana kuesioner dibagikan dan sampel dianggap konsumen akhir.

\section{Teknik Analisis dan Uji Hipotesis}

Untuk mempermudah analisis digunakan aplikasi pengolah data SPSS.

\section{Analisis Regresi Berganda}

Untuk mengetahui pengaruh variabel bebas terhadap variabel terikatnya menurut Sanusi, Anwar (2003:309) digunakan rumus analisis regresi linier berganda sebagai berikut

$$
Y=a+b \underset{1_{1}}{x}+b_{2} x_{2}+b \underset{3}{x}+b \underset{4}{x}+e
$$

$\mathrm{F}_{\text {tabel }}\left(\mathrm{F}_{\mathrm{t}}\right)$ pada $\alpha=0,05$ apabila hasil perhitungannya menunjukkan :

$F_{h}>F_{t}$, maka $H_{0}$ ditolak dan $H_{a}$ diterima

$F_{h}<F_{t}$, maka $H_{0}$ diterima dan $H_{a}$ ditolak

\section{Uji Hipotesis II (Uji t)}

Pengujian dilakukan melalui uji t dengan membandingkan $t_{\text {hitung }}\left(t_{h}\right)$ dengan $t_{\text {tabel }}\left(t_{t}\right)$ pada $\alpha 0,05$. Apabila hasil perhitungan menunjukkan:

$t_{h} \geq t_{t}$ maka $H_{0}$ ditolak dan $H_{a}$ diterima

$t_{h}<t_{t}$ maka $H_{0}$ diterima dan $H_{a}$ ditolak 
Untuk membuktikan hipotesis pertama, yaitu untuk mengetahui besarnya pengaruh secara keseluruhan dihitung koefisien determinasi multiplenya $\left(\mathrm{R}^{2}\right)$. Jika $\mathrm{R}^{2}$ yang diperoleh dari hasil perhitungan mendekati 1 (satu), maka semakin kuat model tersebut dapat menerangkan variabel tergantungnya. Kemudian dilakukan pengujian variansnya dengan uji F.

Hipotesis diterima apabila titik lebih besar dari $\quad t \quad(t>t)$ atau diperoleh harga $\mathrm{p}<0,05$.

Untuk membuktikan hipotesis kedua, masing-masing koefisien regresinya diuji dengan uji t. Hasil uji t bermakna apabila diperoleh $t$ lebih besar dari $t \quad(t>t)$ atau diperoleh harga probabilitas signifikannya $<0,05(\alpha)$. Untuk pengaruh yang dominan ditentukan oleh koefisien regresi terbesar.

\section{HASIL DAN PEMBAHASAN}

\begin{tabular}{|c|c|c|c|}
\hline Variabel & Koefisien Regresi & t hitung & $\begin{array}{c}\text { Prob. } \quad \text { (sig. t }) \\
(\alpha=\mathbf{0 , 0 5 )}\end{array}$ \\
\hline $\mathrm{X}_{1}$ (Kebudayaan) & 0.117 & 0.810 & 0.424 \\
\hline $\mathrm{X}_{2}($ Sosial $)$ & 0.155 & 1.441 & 0.159 \\
\hline $\mathrm{X}_{3}$ (Pribadi) & 0.266 & 3.400 & 0.002 \\
\hline $\mathrm{X}_{4}$ (Psikologis) & 0.464 & 5.201 & 0.000 \\
\hline Konstata & 0.102 & & \\
\hline F hitung & 550.850 & & \\
\hline Adjust $\mathrm{R}^{2}$ & 0.983 & & \\
\hline $\mathrm{R}$ Square $\left(\mathrm{R}^{2}\right)$ & 0.984 & & \\
\hline $\mathrm{R}$ & 0.992 & & \\
\hline $\begin{array}{c}\text { Variabel terikat }=\mathrm{Y} \text { (Keputusan } \\
\text { Pembelian produk) }\end{array}$ & & & \\
\hline
\end{tabular}

\section{A. Analisis Regresi Linier Berganda}

$Y=0,117 X+0,155 X+0,266 X+0,464 X$

$\mathrm{a} \mathrm{b}_{1}=0,117$ adalah besarnya koefisien regresi variabel bebas $\mathrm{X}$ Kebudayaan yang berarti setiap peningkatan (penambahan) variabel X kebudayaan berupa peningkatan pergeseran budaya, wilayah geografis, dan kelas sosial akan meningkatkan variabel terikat Y (keputusan pembelian produk) sebesar 0,117. Dengan asumsi variabel bebas lainnya $(X, X$, dan $X)$ konstan. Jika variabel kebudayaan, ada kecenderungan meningkat maka keputusan pembelian akan meningkat. Jika variabel kebudayaan ada kecenderungan menurun maka keputusan konsumen juga akan menurun.

$\mathrm{b}_{2}=0,155$ adalah besarnya koefisien regresi variabel bebas $\mathrm{X}$ sosial yang berarti setiap peningkatan (penambahan) variabel $\mathrm{X}$ sosial berupa mengikuti lingkungan, pengalaman anggota keluarga dan mengikuti teman akan meningkatkan variabel terikat $Y$ (keputusan pembelian produk) sebesar 0,155. Dengan asumsi variabel bebas lainnya (X, X , dan X ) konstan. Jika variabel sosial, ada kecenderungan meningkat 
maka keputusan pembelian akan meningkat. Jika variabel sosial ada kecenderungan menurun maka keputusan konsumen juga akan menurun.

$b_{3}=0,266$ adalah besarnya koefisien regresi variabel bebas $X$ pribadi yang berarti setiap peningkatan (penambahan) variabel $X$ pribadi berupa uang sak̉u, situasi ekonomi dan gaya hidup akan meningkatkan variabel terikat Y (keputusan pembelian produk) sebesar 0,266. Dengan asumsi variabel bebas lainnya (X, X , dan X ) konstan. Jika variabel pribadi, ada kecenderungan meningkat maka keputusan pembelian akan meningkat. Jika variabel pribadi ada kecenderungan menurun maka keputusan konsumen juga akan menurun.

$\mathrm{b}_{4}=0,464$ adalah besarnya koefisien regresi variabel bebas $\mathrm{X}$ psikologis yang berarti setiap peningkatan (penambahan) variabel $X$ psikologis berupa motivasi, persepsi dan pengetahuan akan meningkatkan variabel terikat $Y$ (keputusan pembelian produk) sebesar 0,464 . Dengan asumsi variabel bebas lainnya $\left(X_{1}, X_{2}\right.$, dan $\left.X_{3}\right)$ konstan. Jika variabel psikologis, ada kecenderungan meningkat maka keputusan pembelian akan meningkat. Jika variabel psikologis ada kecenderungan menurun maka keputusan konsumen juga akan menurun.

Dari persamaan regresi tersebut dapat dilihat bagaimana pengaruh variabel bebas $\left(\mathrm{X}_{1}, \mathrm{X}_{2}, \mathrm{X}_{3}, \mathrm{X}_{4}\right)$ terhadap variabel terikat $(\mathrm{Y})$. Pengaruh positif menunjukkan bahwa perubahan variabel bebas $(\mathrm{X}, \mathrm{X}, \mathrm{X}, \mathrm{X})$ akan searah dengan perubahan keputusan pembelian konsumen (Y)

\section{B. Uji F (Pengujian Hipotesis I)}

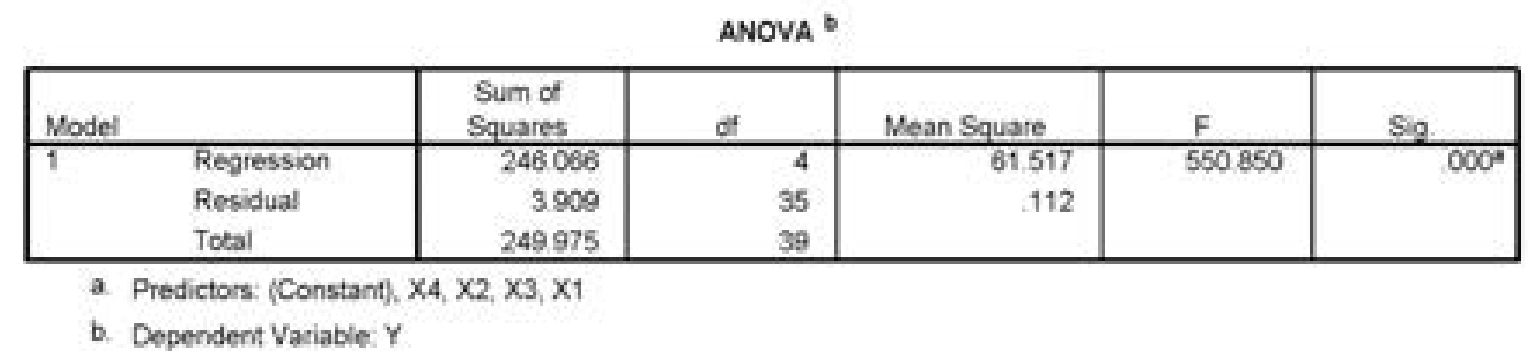

Sumber : Data Diolah

Dari tabel di atas didapatkan hasil $F_{\text {hitung }} 0.000$, serta df penyebut 4 dan df pembilang sebesar 35 .

Untuk menguji hipotesis pertama: diduga bahwa faktor kebudayaan, sosial, pribadi dan psikologis secara bersama-sama berpengaruh terhadap keputusan pembelian produk air minum merk aqua digunakan Uji F. Uji F dilakukan dengan membandingkan $\mathrm{F}_{\text {hitung }}$ dengan $\mathrm{F}_{\text {tabel }}$ pada taraf nyata $\alpha=0,05$

Berdasarkan tabel 4.10 dapat disimpulkan bahwa $F_{\text {hitung }}$ sebesar 550,850 > dari $\mathrm{F}_{\text {tabel }}$ 2,63 yang berarti bahwa pada taraf nyata $\alpha=0,05$ variabel faktor budaya $\left(\mathrm{X}_{1}\right)$, sosial $\left(\mathrm{X}_{2}\right)$, pribadi $\left(\mathrm{X}_{3}\right)$ dan psikologis $\left(\mathrm{X}_{4}\right)$ secara simultan / bersama-sama mempunyai pengaruh signifikan (bermakna) terhadap keputusan pembelian produk air minum merk aqua (Y) dapat diterima atau teruji pada taraf nyata $\alpha=0,05$. Selain itu untuk mengetahui signifikansi pengaruh variabel terikat terhadap variabel bebas secara bersama-sama dengan 
membandingkan antara probabilitas signifikan $(0,000)$ dengan $\alpha(0,05)$. Dimana, jika probabilitas $<\alpha$ maka variabel bebas secara bersama-sama berpengaruh signifikan terhadap variabel terikat. Dengan demikian hipotesis I teruji secara statistik.

\section{Uji t (Pengujian Hipotesis II)}

Untuk menguji hipotesis kedua yang menyatakan bahwa diduga variabel psikologis $\left(\mathrm{X}_{4}\right)$ mempunyai pengaruh yang dominan terhadap keputusan pembelian produk air minum merk aqua (Y), maka dalam penelitian ini melihat besarnya masing-masing nilai $\mathrm{t}$ dari variabel bebas. Adapun signifikasi dari masing-masing koefisien diuji dengan menggunakan uji parsial t-test tampak pada tabel sebagai berikut:

Tabel 2 : Perbandingan $t_{\text {hitung }}$ dengan taraf signifikan $(\alpha=5 \%)$

\begin{tabular}{|c|c|c|c|c|}
\hline Variabel & $\begin{array}{c}\text { Nilai } \\
\mathbf{t}_{\text {hitums }}\end{array}$ & $\begin{array}{c}\text { Nilai } \\
\mathbf{t}-{ }_{\text {tahel }}\end{array}$ & $\begin{array}{c}\text { Prob. } \\
\text { Sig. } \mathbf{t}\end{array}$ & Keterangan \\
\hline $\mathrm{X}_{1}$ & 0.810 & 2.021 & 0.424 & Tidak signifikan \\
$\mathrm{X}_{2}$ & 1.441 & 2.021 & 0.159 & Tidak signifikan \\
$\mathrm{X}_{3}$ & 3.400 & 2.021 & 0.002 & Signifikan \\
$\mathrm{X}_{4}$ & 5.201 & 2.021 & 0.000 & Signifikan \\
\hline
\end{tabular}

Sumber : Data primer yang diolah.

Dari tabel 2 dapat diketahui

Hasil koefisien thitung variabel pribadi (X ) mempunyai nilai thitung sebesar $(3,400)$ lebih besar dibandingkan dengan nilai tabel pada taraf signifikan sebesar $(0,002)$, atau dapat dikatakan variabel pribadi (X) mempunyai pengaruh signifikan terhadap keputusan pembelian produk air minum merk aqua $(\mathrm{Y})$.

Hasil koefisien thitung variabel psikologis (X ) mempunyai nilai t hitung sebesar $(5,201)$ lebih besar dibandingkan dengan nilai $t$ tabel pada taraf signifikan sebesar $(0,000)$, atau dapat dikatakan variabel psikologis (X ) berpengaruh signifikan terhadap keputusan pembelian produk air minum merk aqua $(\mathrm{Y})$.

Dari tabel di atas dapat dijelaskan juga bahwa variabel psikologis (X ) mempunyai

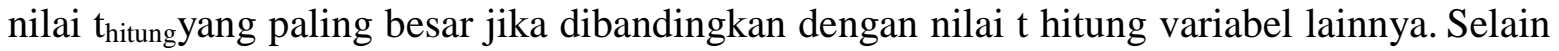
itu juga diketahui koefisien regresi variabel psikologis (X) yang lebih besar dibandingkan koefisien regresi lainnya. Sehingga hipotesis kedua yang menyatakan bahwa variabel psikologis berpengaruh dominan terhadap keputusan pembelian produk air minum merk aqua teruji secara statistik

\section{D. $\mathbf{R}$ square $\left(\mathbf{R}^{2}\right)$}

Dari hasil analisis diperoleh nilai adjusted $R$ square $\left(R^{2}\right)$ sebesar 0,983 hal ini menunjukkan bahwa variabel bebas $\left(\mathrm{X}_{1}, \mathrm{X}_{2}, \mathrm{X}_{3}\right.$, dan $\left.\mathrm{X}_{4}\right)$ secara bersama-sama memberikan kontribusi terhadap variabel terikat $\mathrm{Y}$ (keputusan pembelian produk air minum merk aqua) sebesar 98,3\% dan setelah disesuaikan nilai sisanya sebesar $1,7 \%$ dipengaruhi oleh variabel lain yang tidak dimasukkan dalam penelitian ini. 


\section{Kesimpulan}

Berdasarkan hasil penelitian yang telah dilakukan berikut disampaikan kesimpulan:

1. Dari hasil analisis didapatkan bahwa variabel faktor budaya, sosial, pribadi dan psikologis secara terpisah, faktor pribadi dan faktor psikologis mempunyai pengaruh yang bermakna terhadap keputusan pembelian produk air minum merk aqua.

2. Dari hasil analisis didapatkan bahwa faktor budaya, sosial, pribadi dan psikologis secara bersama-sama mempunyai pengaruh bermakna terhadap keputusan pembelian produk air minum merk aqua.

3. Variabel psikologis mempunyai pengaruh dominan terhadap keputusan pembelian produk air minum merk aqua.

\section{Saran}

Dari hasil penelitian, analisis dan kesimpulan di atas, berikut beberapa saran yang dapat disampaikan:

1. Mengingat keberadaan air aqua di kalangan pelanggan Kecamatan Kota Kediri mudah didapat, harga terjangkau, qualitas terjamin dan adanya iklan. Hendaknya kondisi tetap terjaga agar konsumen tidak berpindah ke merk lain dengan demikian saluran distribusi perlu di jaga.

2. Karena pengaruh faktor psikologis yang terdiri dari motivasi, persepsi dan pengetahuan menjadi pertimbangan konsumen dalam melakukan keputusan pembelian pada produk air minum merk aqua, maka perusahaan (produsen air minum merk aqua) lebih hatihati karena dari konsumen yang diteliti yaitu konsumen terlihat keputusan beli merka tidak mudah dipengaruhi oleh orang lain, daya beli sedang dan kebanyakan sudah berpenghasilan sehingga faktor perimbangan harga dan kualitas menjadi pertimbangan tersendiri.

\section{DAFTAR PUSTAKA}

Arikunto, Suharsimi. 1998. Prosedur Penelitian Suatu Pendekatan Praktik. Edisi Revisi. Cetakan Kesembilan. Rineka Cipta. Jakarta.

Assauri, Sofjan. 1999. Manajemen Pemasaran. Penerbit PT. Raja Grafindo Persada Jakarta.

Hasan, Iqbal. 2002. Pokok-Pokok Materi Statistik II: Statistik Inferensial. Penerbit Bumi Aksara. Jakarta.

J. Paul, et.al. 2000. Consumer Behavior. Edisi Keempat. Jilid I.

Kotler, Philip dan AB. Susanto. 2001. Manajemen Pemasaran Indonesia. Buku 2. Salemba empat. Jakarta.

Kotler, Philip. 2000. Manajemen Pemasaran. Jilid 2. Bumi Aksara. Jakarta.

Engel, et all. 2000. Perilaku Konsumen. Edisi Keenam. Jilid I. Binarupa Aksara, Jakarta.

Lamb, Charles. W. et.al. 2001. Pemasaran. Buku I Edisi Pertama. Penerbit Salemba Empat. Jakarta. 
EkoNiKa | Vol. 1, No. 1, April 2016:38 - 49

Mowen. H. 2002. Perilaku Konsumen. Jilid I. Penerbit. Andi. Yogyakarta.

Rismiati, Catur. dan Bondan Sutrisno. 2001. Pemasaran Barang dan Jasa. Kanisius.

Jakarta. Sanusi, Anwar. 2003. Metodologi Penelitian Praktis Untuk Ilmu Sosial dan

Ekonomi. Edisi Pertama. Cetakan Pertama. Penerbit Buntara Media. Malang

Sugiyono. 2004. Metode Penelitian Bisnis. Cetakan Pertama. Penerbit CV. Alpha Beta. Bandung.

Supranto, J. 1997. Metode Peramalan Kuantitatif Untuk Perencanaan Ekonomi dan Bisnis. Rineka Cipta. Jakarta.

Swasta, Basu dan Handoko, T. Hani. 2000. Manajemen Barang dalam Pemasaran. Cetakan Kedua BPFE, Yogjakarta.

Tjiptono, Fandy. 2002. Strategi Pemasaran. Edisi Kedua. Cetakan Keenam. Penerbit. Andy. Yogyakarta. 